\title{
LOGISTIEKE BEPLANNING MET BEHULP VAN SIMULASIEMODELLERING: 'N GEVALLESTUDIE
}

\author{
J.S. LOUBSER, S.E. VISAGIE en W.J. PIENAAR \\ Departement Logistiek \\ Universiteit van Stellenbosch
}

\begin{abstract}
This article gives an overview of the combined use of object-oriented programming and simulation, with the objective of analysing and planning the logistic functions of a firm. An object-oriented simulation approach is used to evaluate the reception and distribution function of a courier firm. Both the reception of and operations (sorting) on the parcels in the plant were simulated. The first objective of the firm was to analyse the productivity of the conveyer belts and workers in the sorting plant of the courier firm. The firm's utilisation of most of its resources is fairly good, but it is possible to obtain a more efficient process by restructuring its activities. Results from the simulation study showed an imbalance in the capacities of the workstations. Some of the workers, especially those to the end of the conveyer belts, spent almost all of their time waiting for parcels to reach them, while those at the beginning were working at maximum capacity. This is mainly due to the layout and structure of the system. The biggest bottleneck in the system was the capacity of the coupling between two of the conveyer belts. The conclusion was that the firm should seriously consider redesigning the plant. This is the first computer model of the firm's business activities that can be used as a planning tool, and fills a gap in its current planning function. This simulation can be used to determine where and how workers should be applied in the sorting process. The complete simulation model reaches its potential when used as a strategic operational tool, by forecasting the expected results from changing operations and plant layout. A new plant layout has been proposed to the firm, which the model shows to result in substantial improvements in the productivity of the workers, allowing a reduction in their numbers.
\end{abstract}

\section{OPSOMMING}

Hierdie artikel bied 'n uiteensetting van die gekombineerde gebruik van objek-georiënteerde programmering en simulasie, met die doel om 'n onderneming se logistieke funksies te ontleed en te beplan. Die huidige bedryfstelsel van 'n koerieronderneming se ontvangs- en verspreidingsaanleg word geëvalueer deur gebruik te maak van 'n objek-georiënteerde simulasie. Uit die simulasieresultate blyk dit dat daar ' $n$ wanbalans in die kapasiteitsbelading van sommige werkstasies bestaan. Die onderneming se benutting van die meeste van sy hulpbronne is redelik goed, maar deur 'n herstrukturering van aktiwiteite is dit moontlik om 'n meer doeltreffende stelsel te verkry. Die model is die eerste rekenaarmatige voorstelling van 
die onderneming se aktiwiteite, en vul 'n leemte in die beplanningsfunksie. Aangesien die model die verwagte resultate van aanpassings in die werkswyse en/of fisiese veranderinge aan die aanleg kan bereken, kan dit ook gebruik word vir strategiese besluite.

\section{INLEIDING}

Enige onderneming moet voortdurend aandag skenk aan die doeltreffendheid en doelmatigheid van sy werksaamhede. In hierdie artikel word ondersoek ingestel na die bedryfsdoeltreffendheid van 'n koerieronderneming. Tans beskik hierdie onderneming nie oor wetenskaplike ontledings van sommige van sy bedryfsprosesse nie. Een sodanige proses wat nog bestudeer moet word, is die werksverdeling van elkeen van die sorteerpersoneel in die aanleg waar die pakkette vir verdere distribusie gesorteer word. Dit impliseer dat daar ondersoek ingestel moet word na die hoeveelheid werk wat by elke werkstasie verrig word. Die gebruik van 'n simulasiemodel van die sorteeraanleg behoort hierdie tekortkoming te oorbrug. 'n Voorstelling van die vloei van pakkette deur die stelsel, wat aantoon watter invloed elke werkstasie op die vloei uitoefen, kan as 'n nuttige hulpmiddel vir die onderneming aangebied word. 'n Simulasiemodel van die stelsel kan so 'n voorstelling bied. Moderne tegnologie word reeds aangewend om sekere van die prosesse te monitor. Voorbeelde hiervan is die erkenning van ontvangs en versending van pakkette, in die vorm van 'n staafkodeleser, en die kodering van alle pakkette met staafkodes.

\section{AGTERGROND}

Die aanleg wat ondersoek is, is ' $n$ hanteringfasiliteit in 'n stelsel van geskakelde aanlegte, wat saamwerk om die ontvangs, sortering, stoor en versending van pakkette uit te voer. Die hoofdoelwit is om 'n betroubare diens aan kliënte te lewer. Die onderneming wil kliënte ook tevrede stel deur aandag te gee aan kwaliteitsaspekte soos die aflewering van pakkette op die regte plek, op die regte tyd, en in 'n goeie toestand.

Die aanlegte word as eenheid bestuur volgens die as-en-speek-beginsel. Hierdie stelsel hou voordele in vir 'n pakketkarweier. Daar is doeltreffende beheer oor die ontvangs- en verspreidingsproses, en 'n groter gebied kan hierdeur bedien word, as wat die geval sou wees met ander metodes van roetebepaling. Ligte voertuie vervoer 'n kleiner hoeveelheid pakkette op daaglikse basis oor korter afstande, terwyl swaarvoertuie oor langer afstande groter vragte tussen die aanlegte kan vervoer. So word die vervoervoordeel van elke modus gebruik, 
naamlik massavrag per swaarvoertuig en kortafstand, ligte vrag per ligte voertuig. Die asaanlegte werk ook as eenheid saam. Die een as vul die terugvrag van 'n ander as vir die meeste ritte wat onderneem word. Dit verminder die verliese van leë vraghouers wat in die terugrigting vervoer moet word. Hierdie stelsel se grootste nadeel is dat dubbele vervoer kan voorkom. Aangesien aanlegte saamwerk, en vrag na mekaar versend, gebeur dit dat pakkette na en vanaf as-aanlegte verder vervoer word as wat nodig is. Enkelritte kan in hierdie geval soms laer vervoerkoste teweegbring, omdat vervoer oor korter roetes moontlik is. Die doel van die studie is egter nie om die vervoer tussen asse te simuleer nie, maar die sortering van pakkette binne een as.

'n Doelwit van simulasie is om die werklikheid so getrou moontlik na te boots. Die werklike situasie word nie noodwendig beskryf nie, maar die ware eienskappe van die werklike situasie moet in die simulasiemodel opgeneem word. Indien die werklike situasie dan gesimuleer word, kan die eienskappe van die werklike situasie ondersoek word, en kan moontlike probleme in 'n proses opgespoor word [1]. Veranderinge wat as oplossings vir hierdie probleme kan dien, kan dan in die simulasie ingebou word sodat die invloed van die veranderinge aan die stelsel voorspel kan word. Dit kan onnodige uitgawes aan proefneming met fisiese veranderinge in die stelsel voorkom.

In hierdie artikel word die balansering van kapasiteite tussen werkstasies op die sorteerband gesimuleer. Die simulasie word ook gebruik om 'n werksfunksie vir elke personeellid te beskryf sodat oortollige werkstasies (wat oortollige personeel impliseer) of werkstasies met te veel ledige tyd, uit die stelsel verwyder kan word.

\section{KONSTRUKSIE VAN DIE MODEL}

Die veranderlikes wat in die model ondersoek word, is soos volg:

- Die aantal pakkette wat elke voertuig na die aanleg bring;

- die aantal pakkette wat in elke voertuig gepak word;

- die aantal werkstasies wat beman word; en

- die spoed waarteen hanteringstoerusting pakkette deur die aanleg vervoer.

Die veranderlikes wat in hierdie studie as konstant beskou word, is soos volg:

- Die aantal voertuie wat per tydseenheid arriveer; 
- die tyd wanneer elke voertuig arriveer;

- die tye wanneer voertuie met houers moet vertrek;

- die dravermoë van elke voertuig;

- die kapasiteit van die hanteringstoerusting;

- die personeel se hanteringstempo van pakkette;

- die grootte en gewig van pakkette;

- die volgorde van werkstake wat op pakkette uitgevoer word; en

- die gemiddelde aankomstempo van pakkette in die stelsel.

Die volgende aannames geld vir hierdie simulasiemodel:

1. Elke pakket het 'n standaardgrootte en -gewig. Vir hierdie model word aanvaar dat alle pakkette kubusvormig is met 'n sylengte van 0.75 meter. Hierdie grootte verteenwoordig ruweg die gemiddelde grootte van die pakkette.

2. Die hanteringstye van pakkette verskil nie beduidend nie. (Hierdie aanname is realisties omdat alle pakkette vir die werknemers relatief maklik hanteerbaar is.)

3. Die voertuie bedien redelik konstante roetes en normaalweg dieselfde kliënte, wat hulle aankoms- en vertrektye betreklik konstant maak.

Die hoofobjekte wat in die model gebruik word, is (1) 'n bronobjek wat die aankoms van pakkette voorstel, (2) 'n bufferobjek wat die kontrolepunt van die pakkette voorstel, (3) 'n lynobjek wat die vervoerband voorstel, (4) 'n sorteerobjek wat die werkstasies (of aflaaipunt) voorstel, (5) dreinobjekte wat die pakkette stoor nadat dit hanteer is, en (6) metode-objekte wat beskryf hoe take verrig word.

Die lynobjekte in die model is elk 9 m lank en beweeg teen snelhede van onderskeidelik 0.3 en $0.7 \mathrm{~m} / \mathrm{s}$. Die vervoerbandstelsel word dus voorgestel as langwerpige eenhede wat slegs die op- en aflaai van pakkette aan die eindpunte daarvan toelaat. Die werklike situasie stem hiermee ooreen, en min stelseleienskappe gaan weens hierdie aanname verlore.

Die bufferobjekte in die stelsel beskryf die kontrolepunte van die ontvangs en verspreiding van pakkette, wat tans deur werknemers met elektroniese staafkodelesers beman word. Elke pakket word by plasing op die vervoerband met die staafkodeleser geregistreer as binne die 
stelsel, en weer geregistreer as buite die stelsel wanneer dit die stelsel verlaat, deur die verpakking daarvan in 'n houer of op 'n palet. Die hoofdoelwit van hierdie stelsel is nie om kontrole uit te oefen oor die volledigheid van besendings nie, maar om diefstal te voorkom, en om die oorsake van logistieke probleme uit te wys.

Metode-objekte word gebruik en tussen ander objekte verdeel, maar beskryf in die meeste gevalle die manier waarop 'n aktiwiteit uitgevoer word. Die $\mathrm{C}++$ programmeertaal word in die metodes gebruik, en spel die logika van die model uit. 'n Metode in SIMPLE++ is soortgelyk aan 'n reeksopdrag (Eng.: macro) in sigbladprogramme. Beide funksies voer 'n opeenvolgende ketting van opdragte uit, wat verander na gelang van die nakoming, al dan nie, van sekere geprogrammeerde vereistes. Die keuse van sagteware vir die simulasie het op SIMPLE++ geval omdat die sagteware goeie grafiese vemoeëns het (die bestuur van die onderneming vir wie hierdie studie gedoen is, wou die gedrag van die gesimuleerde model "sien") en omdat hierdie sagteware in die departement beskikbaar was.

Daar moet aan 'n hele aantal voorwaardes voldoen word voor die simulasiemodel betekenisvolle resultate sal lewer. Data wat gebruik word vir die aantal pakkette wat daagliks ontvang word, is verkry vanuit die werklike ontvangsdata vir 'n tydperk van drie maande. Hierdie tydperk word deur die bedryfsbestuurder van die onderneming as 'n statisties verteenwoordigende periode beskou omdat die onderneming hiertydens tipiese gedrag vertoon het.

Die ontvangs- en verspreidingsfunksie van die aanleg word vir die daaglikse tydperk 17:00 tot 22:00 gesimuleer. Hierdie proses sluit die hele hanteringsiklus van die onderneming in. Die omgekeerde proses hiervan vind daagliks tussen 02:00 en 07:00 plaas. Die simulasiemodel kan dus geldig wees vir beide prosesse indien die programmeerder 'n aantal klein veranderinge aan die program aanbring. Die eerste nagskof het hoofsaaklik met die ontvangs en hantering van pakkette te doen, terwyl die tweede nagskof hoofsaaklik met die hantering en versending van pakkette te doen het.

Pakkette word slegs in enkelformaat tot die proses toegelaat. Pakkette kan mekaar nie verbysteek sodra dit die vervoerband bereik nie, en word weer in enkelformaat by die onderskeie stasies uit die stelsel verwyder. Die simulasiemodel strek oor die tydperk vanaf 
die oomblik dat 'n pakket vanuit die voertuig gelaai, en dus ontvang word, totdat dit weer in die versendingsvoertuig of op die palet geplaas word.

Die onderskeie funksies van inligtinghantering word saam met die hanteringstyd vir elke item in berekening gebring. Die oorhoofse hantering van inligting word nie in hierdie simulasiegang in berekening gebring nie, aangesien dit onafhanklik van die sorteerproses kan geskied.

Volgens Keller en Warrack [2] is die normaalverdeling 'n getroue voorstelling van die verdeling van die steekproefgemiddelde van steekproewe wat op ewekansige wyse uit enige populasie geneem word, mits die steekproewe relatief groot is. Dit staan ook bekend as die sentrale limietstelling, en die akkuraatheid daarvan is afhanklik van die waarskynlikheidsverdeling van die ouerpopulasie, sowel as op die grootte van die steekproef. Hierdie resultaat word inderdaad deur die data bevestig en dus word die normaalverdeling gebruik om die aankomstempo van pakkette in die model te beskryf. Die waardes vir die gemiddelde en standaardafwyking is gekies op grond van die data, toetsresultate van die aankoms en die mening van die werknemers. Die model word oor ' $n$ tydperk van vier tot vyf uur gesimuleer, wat verseker dat die steekproef feitlik net so groot is as die werklike tydperk waarin die sorteering daagliks in die aanleg geskiet.

In Tabel 1 word 'n volledige lys van al die waarskynlikheidsverdelings gegee. Hierdie verdelings is bepaal op grond van die ontleding van werklike data en simulasie resultate. Die verdelings word saam met spesifieke modelname vir elke objek in die model toegeken. Waar daar twee of meer objektipes van dieselfde klas gebruik word, is dit bloot om onderskeid te tref tussen sekere eienskappe van die klas. So byvoorbeeld verskil die begintydstip van die bronne, aangesien voertuie wat die stelsel inkom, nie almal gelyktydig opdaag nie, maar oor 'n tydperk van 'n uur by die aanleg aankom om pakkette af te lewer. Waar tye volgens die normaalverdeling beskryf word, word dit gegee as $\mathrm{N}(\overline{\mathrm{x}}, \sigma, \mathrm{BG}, \mathrm{OG})$ vir die skatting van die parameter $\mu$. BG en $\mathrm{OG}$ is die boonste en onderste grense vir die vertrouensinterval. ' $\mathrm{n}$ Betekenispeil van $\alpha=0.05$ word gebruik, wat impliseer $95 \%$ van die waardes met herhaalde steekproefneming uit die gegewe populasie tussen die boonste en die onderste intervalgrense sal wees. In die uitvoer van 'n simulasie eksperiment verseker hierdie $\alpha$-waarde dat 
betekenisvolle resultate verkry sal word. Tye word in die formaat van ure, minute, sekondes, en breukdele van sekondes gegee.

Tabel 1 Opsomming van die gekose waarskynlikheidsverdelings

\begin{tabular}{|l|l|c|c|c|c|c|c|}
\hline $\begin{array}{l}\text { Objek- } \\
\text { klas }\end{array}$ & $\begin{array}{l}\text { Objek- } \\
\text { tipe }\end{array}$ & $\begin{array}{c}\text { Proses- } \\
\text { tyd }\end{array}$ & $\begin{array}{c}\text { Opstel- } \\
\text { tyd }\end{array}$ & $\begin{array}{c}\text { Herstel- } \\
\text { tyd }\end{array}$ & $\begin{array}{c}\text { Siklus- } \\
\text { tyd }\end{array}$ & $\begin{array}{c}\text { Begin } \\
\text { Tyd }\end{array}$ & $\begin{array}{c}\text { Kapa- } \\
\text { siteit }\end{array}$ \\
\hline Drein & Drain & $\mathrm{N}(5,2,4.2,5.8)$ & 0 & 0 & - & 0 & 1 \\
\hline Bron & VehicleA & $\mathrm{N}(15,5,13,17)$ & 0 & - & - & 0 & 1 \\
\hline & VehicleB & $\mathrm{N}(15,5,13,17)$ & 0 & - & - & $30: 00$ & 1 \\
\hline & VehicleC & $\mathrm{N}(15,5,13,17)$ & 0 & - & - & $1: 30: 00$ & 1 \\
\hline Buffer & Buffer1 & Konstant: 2.00 & 0 & 0 & $\mathrm{~N}(3,1,2.6,3.4)$ & - & 1 \\
\hline & Buffer11 & Konstant: 2.00 & 0 & 0 & $\mathrm{~N}(3,1,2.6,3.4)$ & - & 1 \\
\hline Sorteeder & Sorter & - & 0 & $\mathrm{~N}(3,1,2.6,3.4)$ & $\mathrm{N}(5,1.5,4.4,5.6)$ & - & 3 \\
\hline Lyn & Line1 & 30 & 0 & 0 & - & - & 12 \\
\hline & Line2 & 12.8571 & 0 & 0 & - & - & 12 \\
\hline
\end{tabular}

Daar word in hierdie geval met skofte gewerk en daar kan dus verwag word dat die beste simulasie resultate verkry sal word indien die skofte as sulks gesimuleer word en nie lang simulasiegange waarin stogastiese ewewig bereik word nie. Simulasie eksperimente het bevestig dat dit wel die geval is omdat lang simulasiegange waarin stogastiese ewewig wel bereik word se resultate swak met die werklike data ooreenstem, terwyl die kort simulasiegange se resultate wel met die werklike data ooreenstem.

Die onderneming beskik oor sy eie aanleg wat verdeel is in die bestuursfunksies en bedryfsfunksies. Die bestuursfunksie is nie in die studie ondersoek nie, maar wel die hanteringsfunksies op die fabrieksvloer en die verwante vloei van inligting. Figuur 1 toon 'n skematiese voorstelling van die vloeruitleg van die gesimuleerde area. Die vervoerbande, die onderskeie deponerings- en versendingsareas, sowel as die werknemerstasies is die hoofkomponente van die model. 
Figuur 1 'n Skematiese voorstelling van die vloeruitleg van die sorteerfasiliteit.

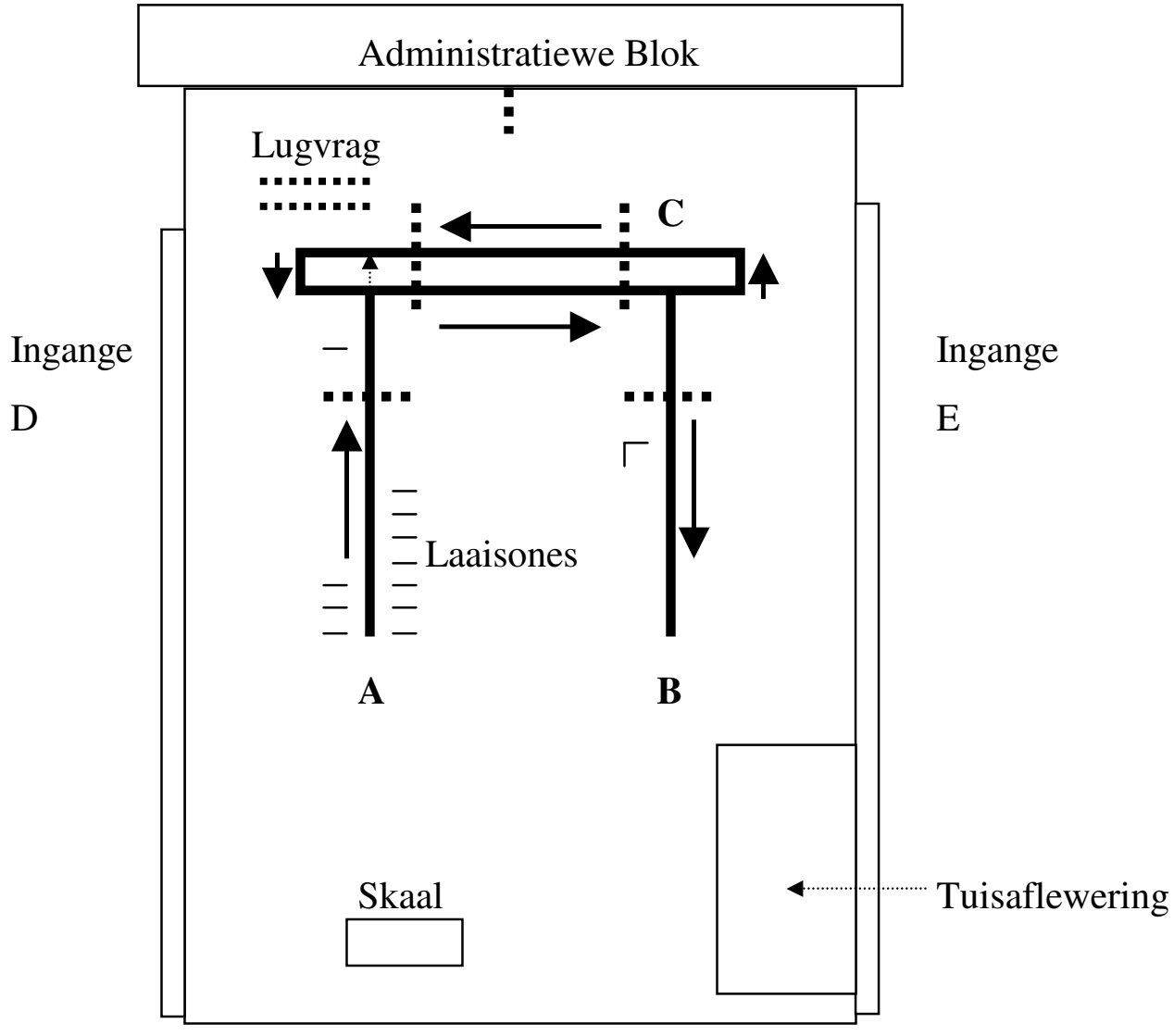

\section{Sleutel:}

Beweegrigting van pakkette op vervoerbande Trappe

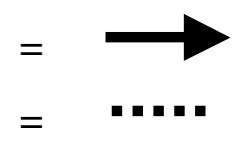

Pakkette word per voertuig deur ingange D en E in Figuur 1 in die stelsel ingebring. Die pakkette word by die onderskeie laaisones afgelaai, en op die vervoerbande geplaas. Hierna volg pakkette 'n vaste roete deur die aanleg. Die pakkette word by die korrekte versendingspunte van die vervoerbande verwyder, en dan in voertuie of op palette gestoor. Sommige pakkette word eers geweeg voor dit by die laaisones in die hanteringstelsel geplaas word.

Die onderneming bedryf ook sy eie tuisafleweringsdiens. Die pakkette wat bestem is om deur hierdie diens hanteer te word, kry 'n spesiale etiket en word eers in 'n afdeling vir tuisaflewerings gestoor. Dié pakkette word met die vervoerband na die korrekte afdeling vervoer, waar dit ontvang en per hand verder hanteer word. 
Die fisiese uitleg word in Simple++ nageboots deur 'n ineenskakeling van drie subraamobjekte binne een hoofraam. In Figuur 2 word die hoofraam getoon. Vanuit die hoofraam kan toegang tot die subrame verkry word. Die hoofraam beskik ook oor die beheermeganisme vir die simulasie, wat deur die simbool van 'n horlosie voorgestel word. Met hierdie objek word die simulasiegang en opname van die resultate beheer. Die simulasiegang kan op enige tydstip gestop of finaal beëindig word. Die eerste objek in die hoofraam is die ontvangs (Eng.: reception) waarin die ontvangs van die pakkette gesimuleer word. Die pakkette wat in hierdie objek volgens gespesifiseerde waarskynlikheidsverdeling geskep word, word dan na die tweede objek aangestuur. Die tweede objek is die hantering (Eng.: operations) waar die sortering van die pakkette gesimuleer word. Die gesorteerde pakkette word dan in die onderskeie stoorobjekte gehou, sodat getoets kan word of die metode-objekte die pakkette reg gesorteer het.

Figuur 2 Hoofraam vir die aanleg in Simple++

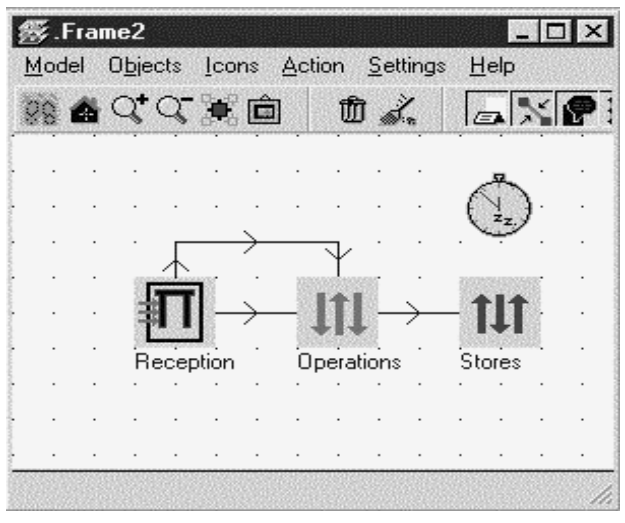

\section{VALIDERING VAN DIE MODEL}

Die validering van die model is gedoen deur die simulasiegange se resultate met die die werklike data te vergelyk. Die onderstaande tabel gee 'n opsomming van hierdie resultate. Vir 'n vollediger vergelyking van resultate kan Loubser [3] geraadpleeg word. Al die resultate vir die simulasie is ook aan die bestuur van die onderneming voorgelê sodat hulle kan besluit of the resultate klop met wat hulle in die praktyk ervaar. Daar is gevind dat die resultate van die simulasie goed klop met die werklike data sowel as die ondervinding van die bestuur. 


\begin{tabular}{|l|r|r|}
\hline Kriteria & $\begin{array}{r}\text { Werklike } \\
\text { data }\end{array}$ & $\begin{array}{r}\text { Simulasie } \\
\text { resultate }\end{array}$ \\
\hline Gemiddelde aantal pakkette per 5 uur skof gesorteer & 4401 & 4443 \\
\hline Standaard afwyking op die aantal pakkette gesorteer & 1320 & 1121 \\
\hline Gemiddelde tyd wat pakkette in stelsel is & $3: 02$ & $3: 07$ \\
\hline Gemiddelde aantal Pakkette deur lynobjek16 hanteer & 1141 & 1148 \\
\hline Gemiddelde aantal pakkette deur Sorteerder21 hanteer & 117 & 113 \\
\hline
\end{tabular}

\section{RESULTATE}

Simulasie resultate kan gebruik en hanteer word soos werklike uitsetresultate, maar kan nie as optimale resultate van 'n stelsel beskou word nie [4]. Die gevolgtrekkings van resultate geld ook net vir die betrokke toestande waaronder die simulasie uitgevoer is. Wanneer enige eienskap van 'n objek binne die stelsel verander word, behoort die hele simulasiegang herhaal te word, sodat nuwe resultate en gevolgtrekkings gemaak kan word.

Die belangrikste resultate van die simulasie wat ondersoek word, is die volgende:

- Aantal pakkette hanteer deur elke werkstasie en die kapasiteit daarvan;

- Totale aantal pakkette deur die stelsel hanteer;

- Ledige tyd en werkstyd van die verskillende werkstasies;

- Relatiewe besetting, wag- en werktyd; en

- Kapasiteite van die verskillende werkstasies.

In Tabelle 2 en 3 word 'n opsomming van die simulasieresultate oor 'n tydperk van vyf uur verskaf. Die volgende aspekte van die resultate word bespreek, wat ook as kolomme in die tabelle opgeneem is:

- Ontvangs en versendings;

- persentasie onbenutte tyd;

- relatiewe besetting (kapasiteitsbenutting);

- persentasie wag- en werktyd;

- persentasie geblokkeerde tyd; en

- persentasie mislukkings

Die aantal keer dat pakkette ontvang word, weerspieël die frekwensie waarteen pakkette in die stelsel moet voorkom. Hierdie frekwensies word gespesifiseer in 'n tabel waarvolgens alle 
bronne in die program hulle pakkette neem. Met die simulasie van 'n vier- tot vyfuurperiode, word nagenoeg die korrekte aantal (wat in die praktyk ondervind word) pakkette vir elke adres gegenereer.

Die aantal versendings vind plaas in ooreenstemming met die aantal wat ontvang is, en die inhoud van elke objek. Uit die "Versend"-kolom in Tabel 2 is dit duidelik dat die vervoerbande (wat deur lyne (Eng.: lines) voorgestel word), verreweg die grootste aantal pakkette in hulle stelsel behou, en ook die stadigste deel van die hanteringstelsel is. Ander aktiwiteite soos sortering (Tabel 3) en verpakking van pakkette neem baie minder tyd in beslag.

Tabel 2 Die simulasieresultate van die ontvangsfunksie.

\begin{tabular}{|l|c|c|c|c|c|c|c|c|c|}
\hline $\begin{array}{c}\text { Objek- } \\
\text { Naam }\end{array}$ & Versend & $\begin{array}{c}\text { Ont- } \\
\text { vang }\end{array}$ & $\begin{array}{c}\text { Leeg } \\
(\boldsymbol{\%})\end{array}$ & $\begin{array}{c}\text { Relatiewe } \\
\text { Besetting } \\
(\boldsymbol{\%})\end{array}$ & $\begin{array}{c}\text { Wagtyd } \\
(\boldsymbol{\%})\end{array}$ & $\begin{array}{c}\text { Werktyd } \\
(\boldsymbol{\%})\end{array}$ & $\begin{array}{c}\text { Geblok } \\
\text {-keer } \\
(\boldsymbol{\%})\end{array}$ & $\begin{array}{c}\text { Maks. } \\
\text { Aantal }\end{array}$ & $\begin{array}{c}\text { Misluk } \\
\text {-king } \\
(\boldsymbol{\%})\end{array}$ \\
\hline Drain1 & 2040 & 2041 & 42.62 & 57.38 & 46.62 & 57.38 & 0 & 1 & 0 \\
\hline Drain2 & 2402 & 2402 & 33.58 & 66.42 & 33.58 & 66.42 & 0 & 1 & 0 \\
\hline Buffer1 & 4447 & 4447 & 50.59 & 49.41 & 50.59 & 49.41 & 0 & 1 & 0 \\
\hline Buffer2 & 13 & 13 & 99.86 & 0.14 & 99.86 & 0.14 & 0 & 1 & 0 \\
\hline LineA & 312 & 324 & 0 & 99.55 & 0 & 8.82 & 90.78 & 12 & 0.4 \\
\hline LineB & 1850 & 1862 & 0 & 97.75 & 0 & 45.14 & 54.53 & 12 & 0.33 \\
\hline LineC & 3393 & 3405 & 0 & 99.92 & 0 & 47.29 & 52.27 & 13 & 0.44 \\
\hline LineD & 4460 & 4472 & 0 & 97.26 & 0 & 62.2 & 37.39 & 13 & 0.41 \\
\hline VehicleA1 & 60 & 61 & 0 & 100 & 0 & 0 & 100 & 1 & 0 \\
\hline VehicleA2 & 30 & 31 & 10 & 90 & 10 & 0 & 90 & 1 & 0 \\
\hline VehicleB1 & 223 & 224 & 20 & 80 & 20 & 0 & 80 & 1 & 0 \\
\hline VehicleB2 & 315 & 315 & 0.25 & 99.75 & 0.25 & 0 & 99.75 & 1 & 0 \\
\hline VehicleC1 & 480 & 480 & 44.24 & 55.76 & 44.24 & 0 & 55.76 & 1 & 0 \\
\hline VehicleC2 & 352 & 352 & 54.32 & 45.68 & 54.32 & 0 & 45.68 & 1 & 0 \\
\hline VehicleD1 & 359 & 359 & 84.34 & 15.16 & 84.34 & 0 & 15.66 & 1 & 0 \\
\hline VehicleD2 & 238 & 238 & 86.41 & 13.59 & 86.41 & 0 & 13.59 & 1 & 0 \\
\hline Line1 & 4443 & 4447 & 0.31 & 26.8 & 0.31 & 99.41 & 0 & 5 & 0.28 \\
\hline Line11 & 4285 & 4288 & 0.38 & 26.1 & 0.38 & 99.3 & 0 & 6 & 0.32 \\
\hline Line12 & 3779 & 3782 & 0.84 & 23.41 & 0.88 & 98.31 & 0 & 6 & 0.51 \\
\hline Line13 & 3463 & 3465 & 2.07 & 21.09 & 2.2 & 97.63 & 0 & 6 & 0.17 \\
\hline Line14 & 3086 & 3087 & 3.29 & 19.17 & 3.63 & 95.93 & 0 & 6 & 0.44 \\
\hline Line15 & 2563 & 2566 & 6.46 & 17.85 & 9.17 & 90.48 & 0 & 6 & 0.35 \\
\hline Line16 & 1147 & 1148 & 33.63 & 8.05 & 40.54 & 59.1 & 0 & 5 & 0.37 \\
\hline Line17 & 270 & 270 & 79.19 & 1.77 & 81.45 & 18 & 0 & 3 & 0.54 \\
\hline Line18 & 0 & 0 & 99.68 & 0 & 99.68 & 0 & 0 & 0 & 0.32 \\
\hline TOTAAL & $\mathbf{4 4 0 1 0}$ & $\mathbf{4 4 0 7 9}$ & $\mathbf{7 5 2 . 0 6}$ & $\mathbf{1 2 1 2 . 0 1}$ & $\mathbf{7 6 8 . 4 5}$ & $\mathbf{9 9 4 . 9 6}$ & $\mathbf{7 3 5 . 4 1}$ & $\mathbf{1 0 5}$ & $\mathbf{4 . 8 8}$ \\
\hline GEM & $\mathbf{1 7 6 0 . 4}$ & $\mathbf{1 7 6 3 . 1}$ & $\mathbf{3 0 . 0 8 4}$ & $\mathbf{4 8 . 4 8 0}$ & $\mathbf{3 0 . 7 3 8}$ & $\mathbf{3 9 . 7 9 8}$ & $\mathbf{2 9 . 4 1 6}$ & $\mathbf{4 . 2}$ & $\mathbf{0 . 1 9 5}$ \\
\hline
\end{tabular}


In die simulasiegang word daar oor vyf uur 4443 pakkette versend. Hierdie getal is verkry uit die totale aantal versendings van die sorteerobjekte (Tabel 3), en is 'n maatstaf waarvolgens die doeltreffendheid van die gemodelleerde stelsel gemeet kan word.

Objekte in die ontvangsfunksie van die model is gemiddeld 30.08 persent van die tyd onbenut. Dié persentasie is realisties omdat daar by verskeie geleenthede tydens die proses oponthoude is, hoofsaaklik vanweë twee redes:

1. Die wisselvallige aantal pakkette wat aankom, en

2. die frekwensie en voorkoms van wagtye wat veroorsaak word deur vervoerbande wat vir kort tye afgeskakel is.

Uit Tabel 3 is die persentasie tyd wanneer die sorteerobjekte onbenut is, 97.77 persent. Hierdie groot ledigheid is onafwendbaar, aangesien sorteerders moet wag op pakkette om hulle werkstasies te bereik. Dit gebeur dikwels dat 'n werkstasie deurentyd beman moet word vir die enkele geleentheid wanneer 'n pakket op daardie punt uit die stelsel geneem moet word. Die huidige vervoerbandstelsel laat min ruimte vir die balansering van kapasiteit. Die ideale proses sou meer ruimte laat vir een sentrale distribusiepunt, waar die adres van pakkette slegs een keer nagegaan word, en dit op dieselfde punt na die onderskeie eindpunte verdeel word. Na afloop van die verdeling van pakkette na hulle eindpunte, kan die verpakkingsfunksie deur een groep werknemers voltooi word. So kan die onderneming ten volle gebruik maak van sy werkersmag, en dubbele werk voorkom word, deur slegs een adresleesfunksie te bedryf.

'n Gemiddelde relatiewe besetting van 48.48 persent vir die ontvangsfunksie is aanvaarbaar. Een probleem in die stelsel word nietemin duidelik wanneer die relatiewe besetting van die bronne nagegaan word. Voertuie laai die pakkette op vervoerband A (Figuur 1) af. Die voertuie wat nader aan vervoerband $\mathrm{C}$ op vervoerband A moet aflaai, moet dikwels vir ruimte op die vervoerband wag om hulle pakkette daarop te plaas. Hierdie probleem veroorsaak die relatief lae besettingsyfer van die ontvangs. Die ander uitvloeisel van hierdie situasie is dat die voertuie wat nader aan vervoerband $C$ aflaai 'n laer benutting as die ander voertuie gaan hê. Hierdie probleem kom ook in die werklikheid voor, wat weereens 'n aanduiding is dat die simulasie ' $n$ getroue weergawe van die werklik situasie is. 
Tabel 3 Simulasieresultate van die sorteerfunksie

\begin{tabular}{|c|c|c|c|c|c|c|c|c|c|}
\hline $\begin{array}{l}\text { Objek } \\
\text { naam }\end{array}$ & Versend & $\begin{array}{l}\text { Ont- } \\
\text { vang }\end{array}$ & $\begin{array}{c}\text { Leeg } \\
(\%)\end{array}$ & $\begin{array}{l}\text { Relatiewe } \\
\text { besetting }\end{array}$ & $\begin{array}{c}\text { Wagtyd } \\
(\%)\end{array}$ & $\begin{array}{c}\text { Werktyd } \\
(\%)\end{array}$ & $\begin{array}{c}\text { Geblok } \\
\text {-keer } \\
(\%)\end{array}$ & $\begin{array}{l}\text { Maks. } \\
\text { aantal }\end{array}$ & $\begin{array}{c}\text { Misluk } \\
\text {-king } \\
(\%)\end{array}$ \\
\hline Sorter1 & 87 & 87 & 99.44 & 0.52 & 100 & 0 & 0 & 1 & 0 \\
\hline Sorter11 & 27 & 27 & 99.5 & 0.17 & 100 & 0 & 0 & 1 & 0 \\
\hline Sorter12 & 41 & 41 & 99.16 & 0.28 & 100 & 0 & 0 & 1 & 0 \\
\hline Sorter13 & 13 & 13 & 99.8 & 0.07 & 100 & 0 & 0 & 1 & 0 \\
\hline Sorter14 & 57 & 57 & 99.1 & 0.3 & 100 & 0 & 0 & 1 & 0 \\
\hline Sorter15 & 163 & 163 & 96.83 & 1.1 & 100 & 0 & 0 & 2 & 0 \\
\hline Sorter16 & 172 & 172 & 96.18 & 1.32 & 100 & 0 & 0 & 2 & 0 \\
\hline Sorter17 & 111 & 111 & 97.81 & 0.74 & 100 & 0 & 0 & 2 & 0 \\
\hline $\begin{array}{l}\text { Sorter18 } \\
\end{array}$ & 88 & 88 & 98.6 & 0.47 & 100 & 0 & 0 & 1 & 0 \\
\hline Sorter19 & 88 & 88 & 98.27 & 0.59 & 100 & 0 & 0 & 2 & 0 \\
\hline Sorter20 & 25 & 25 & 99.51 & 0.16 & 100 & 0 & 0 & 1 & 0 \\
\hline Sorter21 & 113 & 113 & 97.7 & 1.00 & 100 & 0 & 0 & 2 & 0 \\
\hline Sorter22 & 55 & 55 & 98.98 & 0.34 & 100 & 0 & 0 & 2 & 0 \\
\hline Sorter 23 & 78 & 78 & 98.63 & 0.46 & 100 & 0 & 0 & 1 & 0 \\
\hline Sorter24 & 152 & 152 & 97.21 & 0.93 & 100 & 0 & 0 & 2 & 0 \\
\hline Sorter25 & 91 & 91 & 97.88 & 0.71 & 100 & 0 & 0 & 1 & 0 \\
\hline Sorter26 & 7 & 7 & 99.84 & 0.05 & 100 & 0 & 0 & 1 & 0 \\
\hline Sorter27 & 75 & 75 & 98.51 & 0.51 & 100 & 0 & 0 & 2 & 0 \\
\hline Sorter28 & 43 & 43 & 99.71 & 0.21 & 100 & 0 & 0 & 2 & 0 \\
\hline Sorter29 & 395 & 395 & 91.68 & 2.85 & 100 & 0 & 0 & 2 & 0 \\
\hline Sorter30 & 238 & 238 & 95.82 & 1.41 & 100 & 0 & 0 & 2 & 0 \\
\hline Sorter31 & 409 & 409 & 93.74 & 2.17 & 100 & 0 & 0 & 2 & 0 \\
\hline Sorter32 & 437 & 437 & 90.89 & 3.26 & 99.94 & 0 & 0.06 & 3 & 0 \\
\hline Sorter33 & 331 & 331 & 93.67 & 2.2 & 100 & 0 & 0 & 2 & 0 \\
\hline Sorter34 & 132 & 132 & 98.1 & 0.65 & 100 & 0 & 0 & 2 & 0 \\
\hline Sorter35 & 286 & 286 & 98.28 & 1.61 & 100 & 0 & 0 & 2 & 0 \\
\hline Sorter36 & 324 & 324 & 93.72 & 2.15 & 100 & 0 & 0 & 2 & 0 \\
\hline Sorter37 & 135 & 135 & 97.25 & 0.98 & 100 & 0 & 0 & 2 & 0 \\
\hline Sorter38 & 244 & 244 & 95.12 & 1.68 & 100 & 0 & 0 & 2 & 0 \\
\hline Sorter39 & 7 & 7 & 99.86 & 0.05 & 100 & 0 & 0 & 1 & 0 \\
\hline Sorter40 & 12 & 12 & 99.77 & 0.08 & 100 & 0 & 0 & 1 & 0 \\
\hline Sorter41 & 7 & 7 & 99.97 & 0.01 & 100 & 0 & 0 & 1 & 0 \\
\hline Line19 & 0 & 0 & 99.46 & 0 & 100 & 0 & 0 & 0 & 0 \\
\hline Sorter42 & 0 & 0 & 100 & 0 & 100 & 0 & 0 & 0 & 0 \\
\hline Sorter 43 & 0 & 0 & 100 & 0 & 100 & 0 & 0 & 0 & 0 \\
\hline Store11 & 0 & 0 & 100 & 0 & 100 & 0 & 0 & 0 & 0 \\
\hline TOTAAL & 4443 & 4443 & 3519.99 & 29.03 & 3599.94 & 0 & 0.06 & 52 & 0 \\
\hline GEM & 123.4 & 123.4 & 97.77 & 0.806 & 99.998 & 0 & 0.0016 & 1.444 & 0 \\
\hline
\end{tabular}

Die versadigingsvlak van die band kan beïnvloed word deur die spoed waarteen dit loop. Die spoed is verstelbaar, maar vervoerband A moet stadiger as vervoerband B en C gestel word om opeenhopings te voorkom. Hoe vinniger die band loop, hoe hoër is die kapasiteit van die stelsel, hoe meer pakkette kan vervoer word en hoe minder sal die wagtyd by die ontvangs wees. 
Die toelaatbare kapasiteit vir elke objek is geprogrammeer, sodat die maksimum aantal pakkette wat 'n objek dra later hiermee vergelyk kan word ten einde te bepaal tot watter mate die kapasiteit daarvan benut word. Die doel hiervan is om die kapasiteit te balanseer, sodat alle objekte optimaal benut word. Om die kapasiteit van 'n werkstasie te verhoog verg bykomende koste. Die onderneming wil verhoed dat sekere werkstasies hulle kapasiteit ten volle benut, terwyl ander weer nie die beskikbare kapasiteit benut nie. Die kapasiteit moet dus tussen die onderskeie werkstasies gebalanseer word. Die maksimum benutting (kapasiteit) van 'n vervoerband word gegee indien daar elke $0.75 \mathrm{~m}$ 'n pakket daarop geplaas word en dit teen maksimum bandspoed beweeg. Met so ' $\mathrm{n}$ benutting is vervoerband $\mathrm{A}$ in Figuur 1 die kritieke punt in die sisteem wat gesimuleer word. Dit beteken dat vervoerband A die bottelnek in die gesimuleerde sisteem is.

Die relatiewe besetting van die bande vanaf die begin van die stelsel (Line1) tot aan die einde van die stelsel (Line17) daal drasties van 26.8 persent tot 1.77 persent (Tabel 2). Soos pakkette van die band verwyder word, raak dit al leër en eindig op 'n nulpersentbesetting van Line18. Vervoerband A in die ontvangsfunksie het 'n besetting van 99.55 persent, wat net deur 'n mislukking verhoed word om 'n honderdpersentbenutting te hê. 'n Mislukkig is nie 'n breekstilstand nie. Al die voerbande het 'n noodstopknop waar enige sorteer indien die voerband oolaai word die hele proses kan stop. Die druk van hierdie knop word in die simulasie as 'n mislukking gehanteer.

Oor die algemeen het die sorteerders (Tabel 3) 'n onrealisties lae besettingspersentasie, wat hoofsaaklik veroorsaak word deur die keuse van 'n ideale werkstempo. Dit bevestig egter ook dat die sorteerders baie lae benutting het, aangesien die aard van die werk sodanig is dat werknemers verplig word om by een werkstasie te wag op pakkette om hulle te bereik.

Wagtye speel nie 'n baie groot rol in die evaluering van die model nie, aangesien objekte soos sorteerders as deel van hulle taak op pakkette wag. Wagtyd is wel 'n maatstaf by die vervoerband. Die stygende neiging in die persentasie wagtyd vanaf die begin van die stelsel tot aan die einde (Tabel 2, Line 1 tot Line 18) dui op een van die wanbalanse in die stelsel. Die vervoerbande is sodanig ontwerp dat namate die proses vorder, dit al hoe leër raak. Dit is dus onvermydelik dat die bande aan die einde van die vloeikringloop feitlik leeg is, en langer wagtye hier veroorsaak word. 
Die mislukkingsfunksie van ontvangs word geaktiveer om onvoorsiene omstandighede voor te stel wat die proses stop. Die persentasie mislukkings van die ontvangsfunksie is redelik laag, met 'n hoogste waarde van 0.54 persent vir Line17. Daar kan aanvaar word dat 'n sekere persentasie mislukkings in feitlik enige stelsel kan voorkom, en die programmeerder moet die invloed daarvan op die stelsel in ag neem.

\section{GEVOLGTREKKINGS EN AANBEVELINGS}

Die onderneming kan 'n standaardwerksprosedure en -werksmetode ontwikkel waar so ver moontlik standaardtye vir die spesifieke take vereis word. Wanneer elke werknemer binne 'n stel reëls moet werk, behoort die stelsel 'n hoër kapasiteit en werkstempo te hê.

Vervoerband $\mathrm{A}$ in Figuur 1 voed vervoerband $\mathrm{C}$, en by hierdie koppeling ontstaan daar verskeie probleme. Wanneer 'n aantal groter pakkette kort op mekaar volg, ontstaan daar 'n opeenhoping by die koppeling, aangesien die reghoekige rigtingverandering in die vloei nie glad verloop nie. In Figuur 3 word die gebruik van 'n drukplaat aangetoon, wat pakkette gladder oor die koppeling sal laat vloei. Tans word 'n reghoekige plaat gebruik wat voorkom dat pakkette van die vervoerband afgestoot word, en op die vloer beland. Daar word ook 'n ekstra werker aangewend wat slegs die oorgang van pakkette vanaf vervoerband A na vervoerband $\mathrm{C}$ monitor.

Vervoerband C word teen 'n hoër snelheid as vervoerband A bedryf om 'n opeenhoping in die koppelvlak te voorkom. Deur die gebruik van 'n drukplaat kan die kapasiteit van die knelpunt verhoog word, wat beter resultate behoort te lewer as wanneer die spoed van die onderskeie vervoerbande identies is.

Die onderneming gebruik 'n vervoerbandbeheerstelsel wat die noodstop en aanskakeling van elke vervoerband afsonderlik vereis. In die geval van 'n vloeiprobleem sal 'n werknemer tipies vanaf die posisie wat hy/sy beman die vervoerband stop waarop hy/sy werk. Opeenhopings van pakkette vind dus plaas in die koppelvlak tussen opeenvolgende vervoerbande. Dit kan vermy word deur 'n beheerstelsel wat verseker dat een noodstop alle meganiese vloei van pakkette verhoed deur alle vervoerbande te stop. Dit kan ook vanaf 'n sentrale beheerpunt geskied, maar moet verkieslik vanaf die vervoerband self beheer word. 
Dit verseker dat probleme, waarvan die omvang sodanig is dat dit die vloei van pakkette vertraag, by die oorsprong daarvan opgelos word.

Figuur 3 'n Voorgestelde drukplaat vir beter vloei tussen vervoerbande A en C.

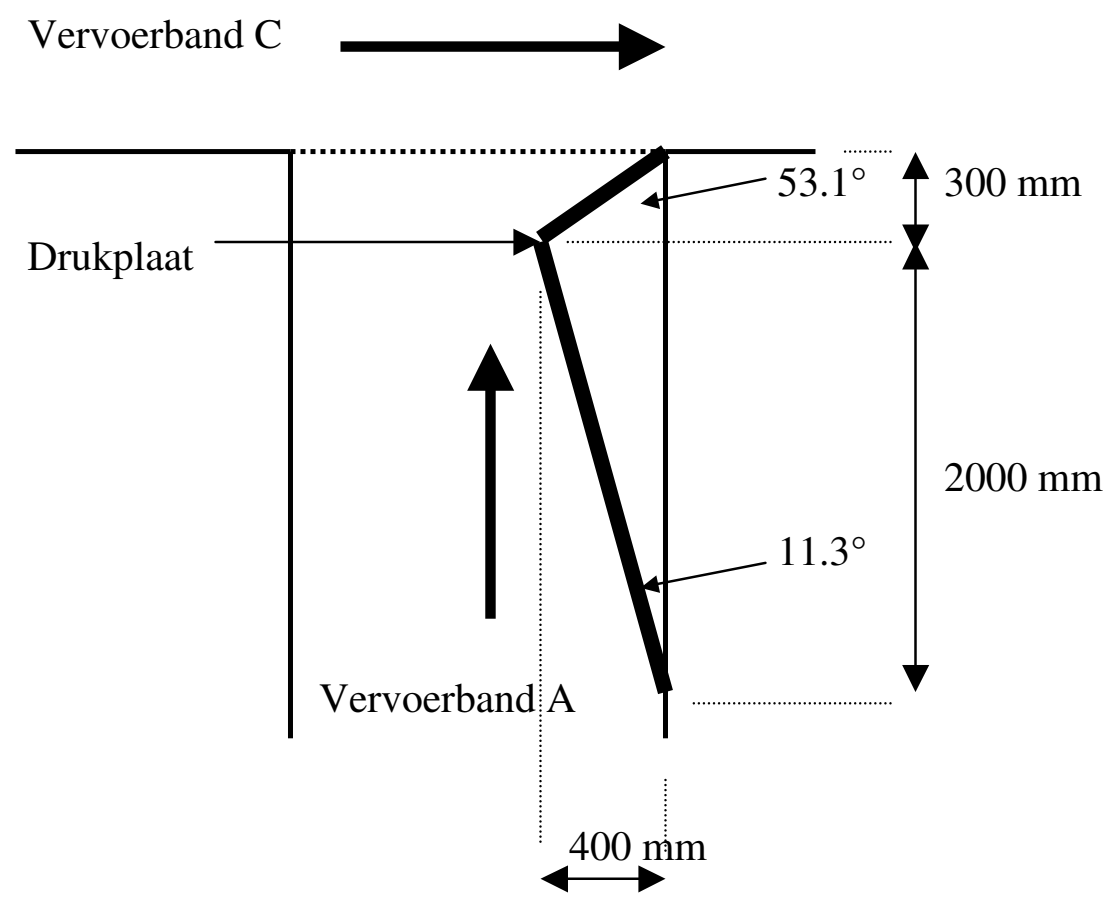

Daar moet ook toegesien word dat die bande teen die maksimum spoed waarby die werkers steeds die pakkette kan hanteer loop, en nie noodwendig teen 'n gemaklike spoed nie. 'n Belangrike beperking op die kapasiteit van die stelsel is die spoed van vervoerband A soos getoon in Figuur 1, wat weer die spoed van vervoerbande B en C beïnvloed.

Daar is verskeie redes vir die herontwerp van die bestaande stelsel. Die huidige uitleg van die aanleg skep vloei- en kapasiteitsprobleme, wat bykomende koste vir die onderneming beteken. Tans word pakkette hoofsaaklik op een punt in die stelsel geplaas, en op verskeie punte weer daaruit onttrek. By elkeen van hierdie punte word die adres op die pakket nagegaan om te verseker dat elke pakket by sy bestemming uitkom. Dit gebeur dus dat die adres op een pakket tot 32 keer nagegaan kan word (32 sorteerders) voor dit die korrekte aflaaipunt bereik. Hantering van pakkette behoort tot die minimum beperk te word. Ideaal gesproke moet die adres van elke pakket net een keer gelees word. 
Sommige pakkette neem etlike minute om uiteindelik die betrokke aflaaipunt te bereik. Die pakket is dus lank in die stelsel, en neem gedurende prosestyd een kapasiteitseenheid in beslag. Hoe langer die pakket neem om deur die stelsel te beweeg, hoe meer beskikbare kapasiteit word daardeur in beslag geneem.

Figuur 4 'n Skematiese voorstelling van 'n aanleg waar die adresse slegs een keer gelees word.

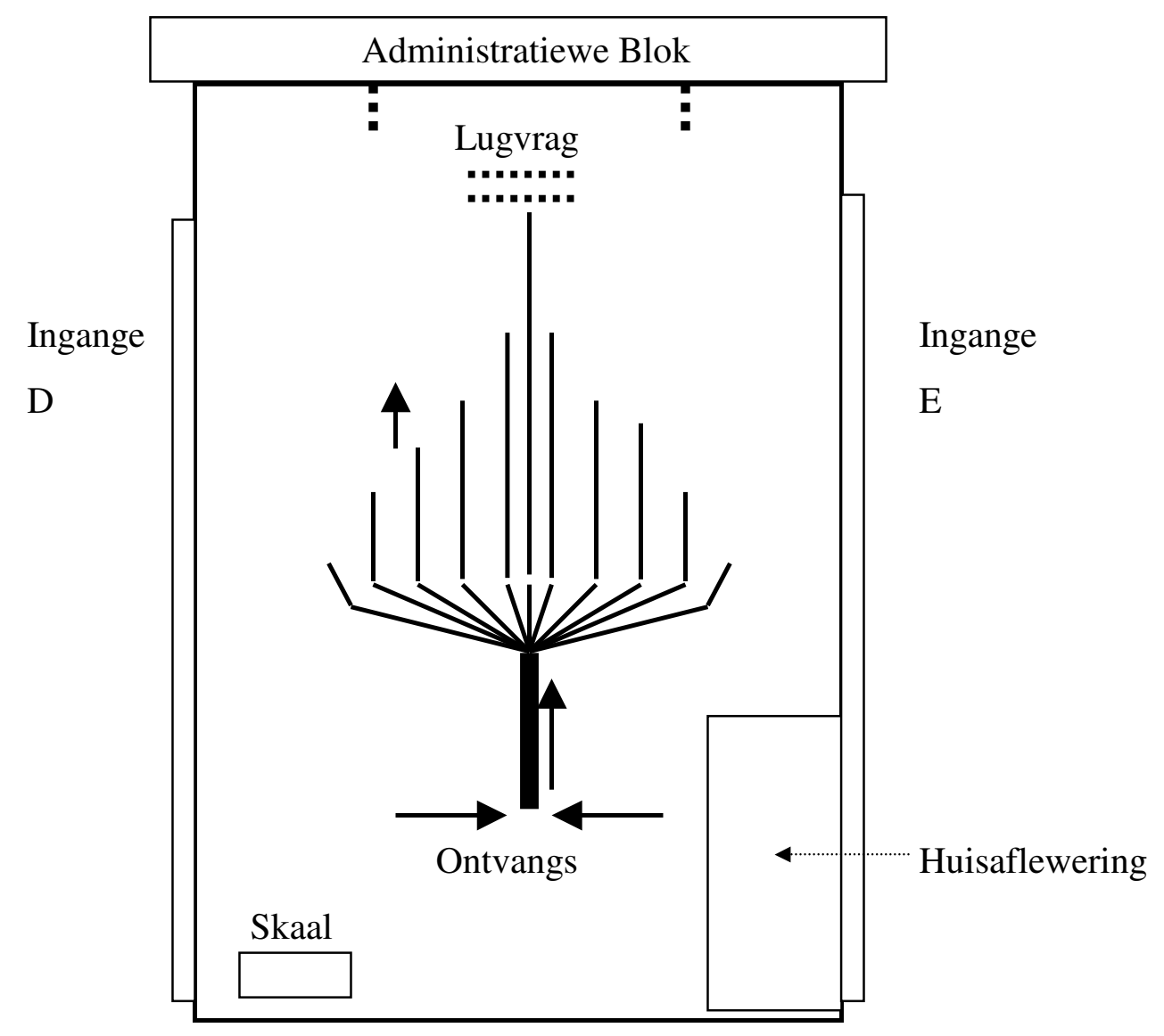

\section{Sleutel:}

Beweegrigting van pakkette op vervoerbande Trappe

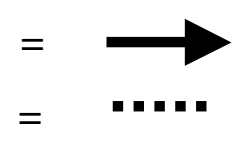

Deur die hele stelsel te herontwerp word die bogenoemde probleme hanteer, maar die kosteimplikasies van die kapitaaluitleg word nie in ag geneem nie. In Figuur 4 is 'n voorstel van 'n aanleg waar die adresse slegs een keer (by die ontvangspunt) nagegaan word. Al die werknemers sal aanvanklik hulle take by hierdie werkstasie verrig, en namate die 
sorteringaktiwiteit vorder, kan hulle een vir een beweeg na die verpakking- en sorteerpunte waarna die pakkette versend word. Een ontvangspunt verseker beter beheer, aangesien pakkette slegs op hierdie punt die stelsel kan binnekom, en weer van dieselfde punt versprei word. Die gemiddelde tydsduur van 'n pakket in die stelsel, totale hanteringstyd, die aantal adreskontrolefunksies, en werknemers se ledige tyd kan verminder word.

Die aanleg kan só ontwerp word dat die ontvangspunt op 'n hoër vlak geleë is as die verpakking- en sorteerpunte. Glybane kan gebruik word om pakkette ná afloop van sortering te vervoer. Wanneer die sorteerfunksie voltooi is en die glybane met pakkette gevul is, kan dieselfde personeel wat pakkette volgens die adresse sorteer het, ook die verpakking behartig.

Die nuwe vervoerbandnetwerk is die grootste verskil tussen die voorgestelde en die bestaande stelsel. Die patroon van een lang netwerk word deur verskeie kort vervoerlyne vervang, wat gevoed word deur een sentrale voerband. Die kapasiteit van hierdie stelsel sal hoofsaaklik bepaal word deur die sorteertempo van die voedingsaar en die verpakkingstempo van die vervoerlyn met die grootste aantal pakkette.

Hierdie stelsel is met 'n simulasie getoets, maar die onderneming vir wie die simulasie gedoen is, het nie hierdie oplossing 'n oorweging nie, omdat dit 'n te groot kapitale uitleg sou veroorsaak. Die simulasie is dus net as 'n akademiese oefening gedoen. Die simulasie het getoon dat die nuwe stelsel, onder meer, die volgende verbeteringe kan teweegbring:

1. Daar is een ontvangspunt, wat die kontrole oor die ontvangste verbeter.

2. Die gemiddelde tyd wat 'n pakket in die stelsel spandeer, verlaag met ongeveer $22.5 \%$.

3. Die werk wat normaalweg in 'n skof van 5 ure afgehandel word, kan in gemiddeld 24 minute korter gedoen word.

4. Die sorteerders kan van 23 na 15 verminder word.

5. Die beperking van hierdie model is letterlik die benutting waarteen die werkers pakkies kan hanteer. Hierdie benutting is ongeveer $60 \%$. Sorteerders kan 'n hoër besetting nie op die lange duur volhou nie.

\section{VERWYSINGS}

[1] R.B. CHASE, N.J. AQUILANO. Production \& Operations Management. Sesde Uitgawe. Irwin, New York, (1992). 
[2] G. KELLER, B. WARRACK, Statistics for Management and Economics. Vierde Uitgawe, Duxbury Press, Johannesburg, (1997).

[3] J.S. LOUBSER, Logistieke beplanning met behulp van abjek-georiënteerde simulasie. MPhil-tesis. Universiteit van Stellenbosch, Stellenbosch, (1999).

[4] G. SALVENDY, (Red.). Handbook of Industrial Engineering. Institute of Industrial Engineers, John Wiley \& Sons Inc., New York, (1992). 
